\title{
Optimization Method for the Synthesis of Fatty Amide Surfactants from Oleic Acid Catalyzed by Immobilized Lipase
}

\author{
ZUHRINA MASYITHAH \\ Department of Chemical Engineering, Faculty of Engineering, \\ University of Sumatera Utara Jl. Almamater Kampus USU Medan 20155, Indonesia. \\ ${ }^{*}$ Corresponding author E-mail: zuhrina@yahoo.com \\ http://dx.doi.org/10.13005/ojc/320310
}

(Received: May 07, 2016; Accepted: June 17, 2016)

\begin{abstract}
Response Surface Methodology (RSM) is successfully used to obtain the optimum conversion of oleic acid on the synthesis of fatty amide surfactants from oleic acid and diethanolamine by immobilized lipase. The central composite design is adopted to determine the optimum level of three study variables, i.e. enzyme amount, substrate molar ratio, and temperature. The model resulted in this study is suitable to represent the interaction among three variables and also their interaction to the conversion of oleic acid. The influence of substrate molar ratio is more significant among others. The prediction of the statistical model shows that the maximum conversion of oleic acid would be $78.01 \%$ at the optimal condition of 5-9\% (wt/wt OA) enzyme amount, $1 / 1$ to $3 / 1$ molar ratio of diethanolamine to oleic acid and $60-65^{\circ} \mathrm{C}$ temperature. The coefficient of determination $\left(R^{2}=0.9897\right)$ shows a high correlation between predicted and experimental values.
\end{abstract}

Keywords: Surfactants, amidification, fatty amide, immobile lipase, Response Surface Methodology.

\section{INTRODUCTION}

Fatty amide is surfactant containing amide bond, where this bond is chemically and physically very stable in alkaline media ${ }^{1}$. This surfactant is a nonionic surfactant and has been developed in the industry because of their emollient and lubricating properties, and low reactivity. Fatty amide also can be produced from natural fats and oil. It is fully biodegradable surfactant and cause less damage to the environment than petroleum chemical surfactants ${ }^{2}$. Fatty amide is the essential ingredient of several formulations such as detergent, shampoos, cosmetics, antibiotics and antifungal agents ${ }^{3,4}$.

One of fatty amide surfactants which has not been widely developed is oleoyl-diethanolamide. Oleoyl-diethanolamide surfactant can be synthesized from oleic acid and diethanolamine. The oleic acid is mostly used in the synthesis of surfactant because the oleic acid can easily be obtained from the fraction of vegetable oil such as crude palm oil (CPO). The availability of CPO is huge and sustain². Diethanolamine is one of the most important material 
of the alkanolamide surfactants due to its polarity level compares to other amides. It contains two hydroxyl groups in the molecule of alkanolamine ${ }^{3}$.

Alkyl-diethanolamide can be obtained in two ways. Firstly is by reacting amines with fatty acid and secondly is by reacting amine with ester ${ }^{1}$. The amidification reaction between amine and fatty acid is preferred to react amine and ester. It is due to the by product of the reaction from amine and fatty acid is water in which more safety than methanol. Water can easily be separated by solving the product with acetone. In case of amide produced by reacting fatty acid methyl ester and amine, methanol as the by product has to be separated by evaporating methanol and the process is carried out at vacuum ${ }^{5}$.

Recently, lipase is widely used as a catalyst in the synthesis of surfactant to replace the chemical catalyst such as zinc oxide $(\mathrm{ZnO})$ and sodium metoxide. Lipase (triacylglycerol hydrolases; EC 3.1.1.3) is extensively used due to their regio-, stereo-, substrate- specificities milder reaction conditions and relatively lower energy requirement ${ }^{2,4}$. Lipase-catalyzed reactions have been carried out in suitable organic solvents or under solvent-free conditions at hydrolysis reaction ${ }^{6}$, esterification ${ }^{7,8,9}$ and amidification ${ }^{3,5,10}$. Most of the work on lipasecatalyzed amidification reported in the literature is based on the reactions using fatty ester substrate. The amidification of long and short chain fatty acid has received little attention.
The selection of lipase for the synthesis of alkanolamide was reported by Tufvesson and associates ${ }^{11}$. They studied two classes of enzyme, i.e. protease and lipase. The result of protease was not significant as lipase because protease was more on certain amino acids and more sensitive under media organics. On the other hand, lipase was more specific because its excellent to hydrolyze $\mathrm{N}-\mathrm{H}$ bond in amine and immobilize lipase was able to work at the temperature of $90^{\circ} \mathrm{C}^{10}$.

The initial work in laboratory has indicated that substrate concentration, temperature and enzyme amount are significantly affected the amidification reaction ${ }^{5}$.

The present investigation is aimed to enhance knowledge about the reaction parameters affecting lipase-catalyzed synthesis of oleoyldiethanolamine and to optimize the process. Therefore, study is needed to increase and to optimize the yield of oleoyl-diethanolamine. The efforts taken for it are not only studying the influence of each reaction variables to the yield, but also studying the interaction effect of variables to the yield and finding the optimum condition.

As optimization is one of the most important engineering tools to create a process economic, safe and environmental friendly, thus in this study optimization is carried out using Central Composite Design (CCD) and analyzed using Response

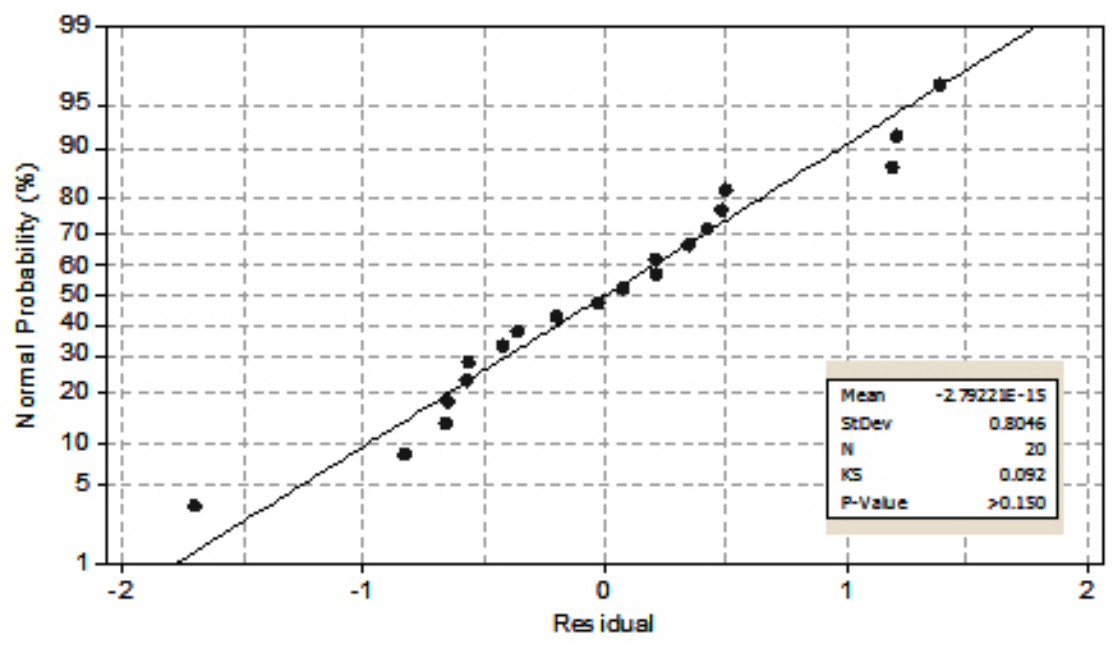

Fig. 1: Normal probability residual plot 
Surface Methodology (RSM) ${ }^{12,13}$. RSM is an efficient statistical tool for optimization of multiple variables to predict the best performance conditions using a minimum number of experiments ${ }^{14}$. It is superior to traditional approach in which optimization studies are carried out by varying one parameter at a time while keeping others constant.

\section{MATERIALS AND METHODS}

\section{Enzyme and chemicals}

Immobilized lipase from Candida antarctica supported on an acrylic resin, from Sigma Aldrich, United States. n-Hexane, diethanolamine (DEA) and oleic acid (OA) are obtained from E Merck, Germany.

\section{Amidification method}

Lipase immobile was employed as the catalyst to perform the amidification of oleic acid with diethanolamine. Amide synthesis was performed in a stoppered flasks with a working volume of $50 \mathrm{~mL}$. An appropriate amount of enzyme was added to the flask containing oleic acid with diethanolamine dissolved in $n$-hexane. The range of values for enzyme amount (5-9\% wt/wtOA), substrate molar ratio (1/1 to $3 / 1$ mol DEA/OA) and temperature (45$65^{\circ} \mathrm{C}$ ) determined from preliminary studies ${ }^{5}$ and varied by central composite design. The reaction mixtures were incubated in an orbital shaker at 350 rpm and at $48 \mathrm{~h}$.

\section{Experimental design}

A five-level, three-variable central composite design (CCD) was adopted in this study ${ }^{13}$. The fractional factorial design was consisted of 16 factorial points, six axial points (two axial points on the axis of each design variable at a distance of two from the design center) and six of center points. The variables, the levels selected, and the actual yield experiments that carried out for developing the model are represented in Table 1.

Table 1: The CCD consisting of experiments for the study of three experimental factors in coded and actual levels with experimental results

\begin{tabular}{|c|c|c|c|c|c|c|c|}
\hline \multirow[t]{2}{*}{$\begin{array}{l}\text { Exp. } \\
\text { no }\end{array}$} & \multicolumn{2}{|c|}{$\begin{array}{l}\text { Enzyme amount, } \\
\mathrm{X}_{1}(\mathrm{wt} / \mathrm{wtOA})\end{array}$} & \multicolumn{2}{|c|}{$\begin{array}{l}\text { Substrate ratio, } \\
\mathrm{X}_{2} \text { (mol DEA/OA) }\end{array}$} & \multirow[b]{2}{*}{ Code } & $\begin{array}{l}\text { Temperature, } \\
\mathrm{X}_{3}\left({ }^{\circ} \mathrm{C}\right)\end{array}$ & \multirow{2}{*}{$\begin{array}{c}\text { Oleic Acid } \\
\text { Conversion, } \\
\text { Y (\%) }\end{array}$} \\
\hline & Code & Actual & Code & Actual & & & \\
\hline 1 & -1 & 5 & -1 & $1 / 1$ & -1 & 45 & 64.2723 \\
\hline 2 & 1 & 9 & -1 & $1 / 1$ & -1 & 45 & 59.1023 \\
\hline 3 & -1 & 5 & 1 & $5 / 1$ & -1 & 45 & 71.2734 \\
\hline 4 & 1 & 9 & 1 & $5 / 1$ & -1 & 45 & 72.9561 \\
\hline 5 & -1 & 5 & -1 & $1 / 1$ & 1 & 65 & 79.0143 \\
\hline 6 & 1 & 9 & -1 & $1 / 1$ & 1 & 65 & 78.3169 \\
\hline 7 & -1 & 5 & 1 & $5 / 1$ & 1 & 65 & 57.6495 \\
\hline 8 & 1 & 9 & 1 & $5 / 1$ & 1 & 65 & 67.3285 \\
\hline 9 & -1.682 & 3.63 & 0 & $3 / 1$ & 0 & 55 & 64.3129 \\
\hline 10 & 1.682 & 10.36 & 0 & $3 / 1$ & 0 & 55 & 67.2623 \\
\hline 11 & 0 & 7 & -1.682 & $1 / 1.4$ & 0 & 55 & 64.9972 \\
\hline 12 & 0 & 7 & 1.682 & $6.4 / 1$ & 0 & 55 & 60.2631 \\
\hline 13 & 0 & 7 & 0 & $3 / 1$ & -1.682 & 38.18 & 77.1412 \\
\hline 14 & 0 & 7 & 0 & $3 / 1$ & 1.682 & 71.82 & 78.2131 \\
\hline 15 & 0 & 7 & 0 & $3 / 1$ & 0 & 55 & 78.3129 \\
\hline 16 & 0 & 7 & 0 & $3 / 1$ & 0 & 55 & 78.3865 \\
\hline 17 & 0 & 7 & 0 & $3 / 1$ & 0 & 55 & 77.8584 \\
\hline 18 & 0 & 7 & 0 & $3 / 1$ & 0 & 55 & 77.2239 \\
\hline 19 & 0 & 7 & 0 & $3 / 1$ & 0 & 55 & 77.3238 \\
\hline 20 & 0 & 7 & 0 & $3 / 1$ & 0 & 55 & 78.0945 \\
\hline
\end{tabular}


The data (percent conversion) shown in Table 1, then analyzed using RSM and the analysis was carried out using the commercial software MINITAB $16^{\circ}$. The RSM is a mathematical methods and statistic techniques which aims to produce model and to determine the relation and the influence of response variable and predictor variables ${ }^{14}$. The response variable in this synthesis is conversion of oleic acid and the predictor variables are enzyme amount, substrate molar ratio and temperature.
For creating the response surfaces then the experimental data which obtained based on the design were fitted to a second order polynomial equation of the form:

$$
\begin{aligned}
& Y=\beta_{1}+\beta_{2} X_{1}+\beta_{3} X_{2}+\beta_{4} X_{3}+\beta_{5} X_{1} X_{2}+\beta_{6} X_{2} X_{3}+ \\
& \beta_{7} X_{1} X_{3}+\beta_{8} X_{1}^{2}+\beta_{9} X_{2}^{2}+\beta_{0} X_{3}^{2}
\end{aligned}
$$

\begin{tabular}{|c|c|c|}
\hline Term & Coef & $\mathbf{P}$ \\
\hline Constant (Y) & 78.141 & 0.000 \\
\hline Enzyme $\left(X_{1}\right)$ & 1.5496 & 0.009 \\
\hline Molar Ratio $\left(\mathrm{X}_{2}\right)$ & -3.5150 & 0.000 \\
\hline Temperature $\left(\mathrm{X}_{3}\right)$ & 1.9826 & 0.002 \\
\hline Enzyme $\left(X_{1}\right)^{*}$ Enzyme $\left(X_{1}\right)$ & -11.7087 & 0.000 \\
\hline Molar Ratio $\left(\mathrm{X}_{2}\right)^{*}$ Molar Ratio $\left(\mathrm{X}_{2}\right)$ & -14.8662 & 0.000 \\
\hline Temperature $\left(\mathrm{X}_{3}\right)^{\star}$ Temperature $\left(\mathrm{X}_{3}\right)$ & -0.0776 & 0.921 \\
\hline Enzyme $\left(\mathrm{X}_{1}\right)^{*}$ Molar Ratio $\left(\mathrm{X}_{2}\right)$ & 6.0914 & 0.000 \\
\hline Enzyme $\left(X_{1}\right)^{*}$ Temperature $\left(X_{3}\right)$ & 4.1463 & 0.002 \\
\hline Molar Ratio $\left(\mathrm{X}_{2}\right)^{*}$ Temperature $\left(\mathrm{X}_{3}\right)$ & -17.6933 & 0.000 \\
\hline \multicolumn{3}{|c|}{$\mathrm{S}=$ squared due to error, residual, deviance $=1.05523$} \\
\hline \multicolumn{3}{|c|}{$\mathrm{R}-\mathrm{Sq}=$ total squared $=98.97 \%$} \\
\hline \multicolumn{3}{|c|}{$\mathrm{R}-\mathrm{Sq}(\mathrm{adj})=$ squares due to treatment $=98.04 \%$} \\
\hline \multicolumn{3}{|c|}{ Unusual Observations for Conversion (\%) } \\
\hline Obs Conversion(\%) & & \\
\hline 79.14 & & \\
\hline 78.213 & & \\
\hline
\end{tabular}

Table 2: The results of prediction on the regression coefficients

Table 3: Analysis of variance for the model

\begin{tabular}{lccccc}
\hline Source & DF & Seq SS & Adj SS & F & P \\
\hline Regression & 9 & 1068.62 & 1068.62 & 106.63 & 0.000 \\
Linear & 3 & 59.64 & 90.31 & 27.03 & 0.000 \\
Square & 3 & 598.56 & 598.56 & 79.18 & 0.000 \\
Interaction & 3 & 410.43 & 410.43 & 122.86 & 0.000 \\
Residual Error & 10 & 11.14 & 11.14 & & \\
Lack-of-Fit & 5 & 9.91 & 9.91 & 8.06 & 0.019 \\
Pure Error & 5 & 1.23 & 1.23 & & \\
Total & 19 & 1079.75 & & & \\
\hline
\end{tabular}

$\mathrm{DF}=$ degrees of freedomSeq $\mathrm{SS}=$ sum squared errorAdj $\mathrm{SS}=$ sum squared increased of variables

$\mathrm{F}=$ distribution $\mathrm{F}$, to test the suitability of the model $\mathrm{P}=\mathrm{P}$ value, to test the suitability of the model 
where, $\mathrm{Y}=$ oleic acid conversion (\%) ; $\beta_{1}=$ intercept (constant) ; $\beta_{2}-\beta_{4}=$ linear coefficient ; $\beta_{5}-\beta_{7}=$ cross product coefficient $; \beta_{8}-\beta_{10}=$ quadratic coefficient ; $X_{1}=$ enzyme amount (wt/wtOA) ; $\mathrm{X}_{2}=$ substrate molar ratio (mol DEA/OA) and $\mathrm{X}_{3}=$ temperature $\left({ }^{\circ} \mathrm{C}\right)$.

\section{Purification, analysis, and characterization}

The amide product was separated from solvent by using the rotary evaporator and then it was washed with acetone to separate amide from the excess substrate. The sample analysis was carried out under qualitative analysis (using a spectrophotometer Proton Nuclear Magnetic Resonance ( ${ }^{1} \mathrm{H}-\mathrm{NMR}$ ) and the conversion of oleic acid was carried out by the following equation:

$$
\% \text { conversion }=\frac{\text { acid value }_{\text {initial }}-\text { acidvalue }_{\text {end }}}{\text { acidvalue }_{\text {initial }}}
$$

\section{RESULTS AND DISCUSSION}

The research is focused on predicting of the model, studying on the influence of interaction among three variables, and determining the optimum conversion that can be obtained from the synthesis of oleoyl-diethanolamide. The selection of solvent, enzyme and reaction time were based on the previous study ${ }^{15}$.

\section{Model development}

In order to avoid a significant deviation on the mathematical model, the initial stage of RSM was carried out by predicting regression model, analyzing of variance and modeling verification. The regression model was aimed to study relation among the percent conversion of oleic acid $(Y)$ and the enzyme amount $\left(X_{1}\right)$, molar ratio of diethanolamine to oleic acid $\left(\mathrm{X}_{2}\right)$ and temperature $\left(\mathrm{X}_{3}\right)$ and also to optimize the respond of oleic acid conversion.

In Table 2, it is shown the results of prediction of regression coefficients to compare the RSM model of oleoyl-diethanolamide synthesis. The $P$ value is used to determine the significance between two variables ${ }^{11}$. From Table 2, all linier coefficients, two quadratic terms (substrate molar ratio and enzyme amount), and all cross product coefficients are highly significant $(P<0.02)$. A quadratic term of temperature is eliminated in the refined equation as the $P$ values of these coefficients are very insignificant $(P>0.5)$.

As a result, the suitable mathematical model to show the relation of reaction variables and its interaction to percentage of oleic acid conversion $(Y)$ in the synthesis of oleoyl-diethanolamide is:

$$
\begin{aligned}
& Y=78.0141+1.5496 X_{1}-3.5150 X_{2}+1.9826 X_{3} \\
& +6.0914 X_{1} X_{2}-17.6933 X_{2} X_{3}+4.1463 \\
& \beta_{7} X_{1} X_{3}-11.7087 X_{1}^{2}-14.8662 X_{2}^{2}
\end{aligned}
$$

The second order regression model obtained then was analyzed by variance analysis and model verification test prior to regression models could be plotted as surface response and contour response. From the prediction coefficient in Table 2 , it is also known that the enzyme amount gives the positive and significant effect of 1.5496 on the product formation. As its interaction with the molar ratio and temperature, the enzyme amount also gives the positive and significant effect of 6.0914 and 4.1463. But squared variable of enzyme amount gives the negative effect of -11.7087 .

The molar ratio of DEA/OA in linier term and in quadratic term gives the negative and significant effect to the conversion of oleic acid as its interaction with temperature also gives the negative and significant effect of -17.6933 . The temperature variable, in linier term has a positive and significant effect of 1.9862 but the quadratic term gives insignificant effect $(P=0.921)$. Thus, it is not included in mathematical model of oleoyldiethanolamide synthesis. It indicates that the rate of enzymatic reaction between oleic acid and diethanolamine is greatly influenced by the enzyme amount, molar ratio of $\mathrm{DEA} / \mathrm{OA}$ and temperature. But those three variables have certain limitations because in enzymatic reaction it is recognized the existence of barriers to the substrate ${ }^{10,16}$.

Accuracy of the model resulted by regression can be seen from the coefficient of determination $\left(R^{2}\right)$ because it reflects the influence exerted by the study variables ${ }^{17}$. The analysis of response surface models 
for oleoyl-diethanolamide synthesis at Table 2 shows the determination coefficient $\left(R^{2}\right)$ of $98.97 \%, R^{2}$ (Adj.) value of $98.04 \%$ and $S$ value of 1.05523 . The greater the value of $\mathrm{R}^{2}$, then the better is the model ${ }^{18}$. Under this $\mathrm{R}^{2}$ value, as much as $98.97 \%$ acquisition of oleic acid conversion was resulted by the three research variables, namely enzyme amount, molar ratio of DEA/OA and temperature.

The commercial application of MINITAB $16^{\circledR}$ statistical analysis was also utilized for the analysis of unusual observation. The unusual observation is a condition where the residual between the observed values with predictions have substantial deviation from the other observations. By the analysis this unusual observation, particularly on the value of deviation, then the value of conversion can be maximized (optimum) for the next step of study. In Table 2, the unusual observations are on the run number 5 and 14. Based on the results of the analysis of percent conversion in Table I, oleic acid conversion which produced by unusual observation
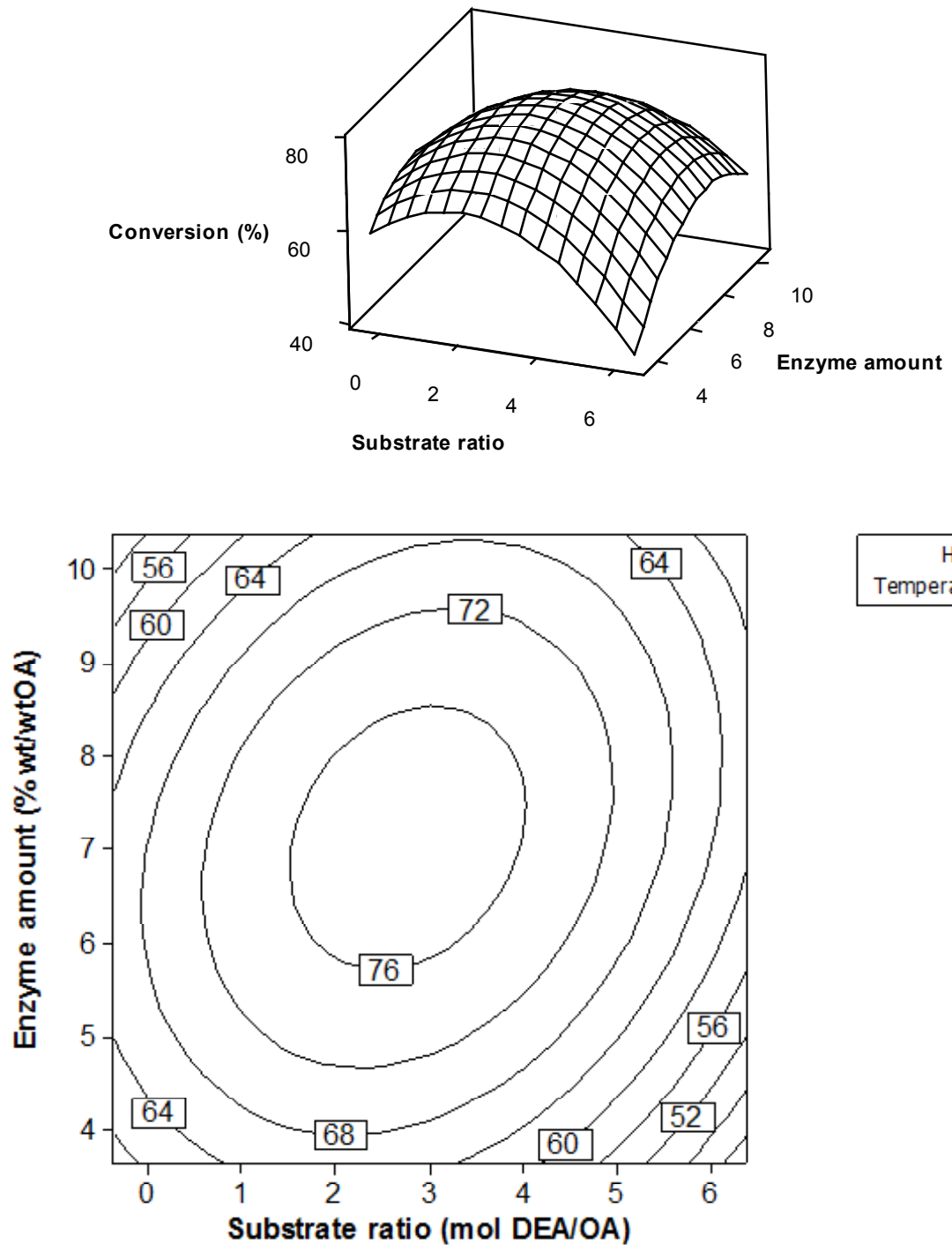

Hold Values Temperature (degC) 55

Fig. 2: Response surface plot and contour plot shows the interaction between substrate molar ratio of DEA/OA and enzyme amount with temperature fixed at $55^{\circ} \mathrm{C}$ 
is of $79.014 \%$ for run number 5 and of $78.213 \%$ for run number 14 .

\section{Analysis of variance}

Analysis of variance (ANOVA) is used to examine the significance of the regression model ${ }^{19}$. The values of the coefficients and the analysis of variance are presented in Table 3 . The results of variance analysis show that the linier model, the quadratic and non linier models, which contain the interaction between the factors are significant $(P$ value for all three is less than a used is 0.05). This means that all three models are appropriate to be used in the synthesis of oleoyl-diethanolamide.

\section{Model verification tests}

Model verification tests were carried out by examining the suitability of the residual with the required assumptions ${ }^{20}$. In this study, normality at the common ANOVA assumption was taken. From normality plot in Fig. 1, it can be seen that the data are distributed around the straight line. The normality is also supported by the fact that the mean residual information is close to zero $\left(-2.79221 \cdot 10^{-15}\right)$. As a result, the regression model can be used to represent the behavior of data.

Analysis of the effect of the interaction variable The influence of interaction among three variables in this study, substrate molar ratio, enzyme
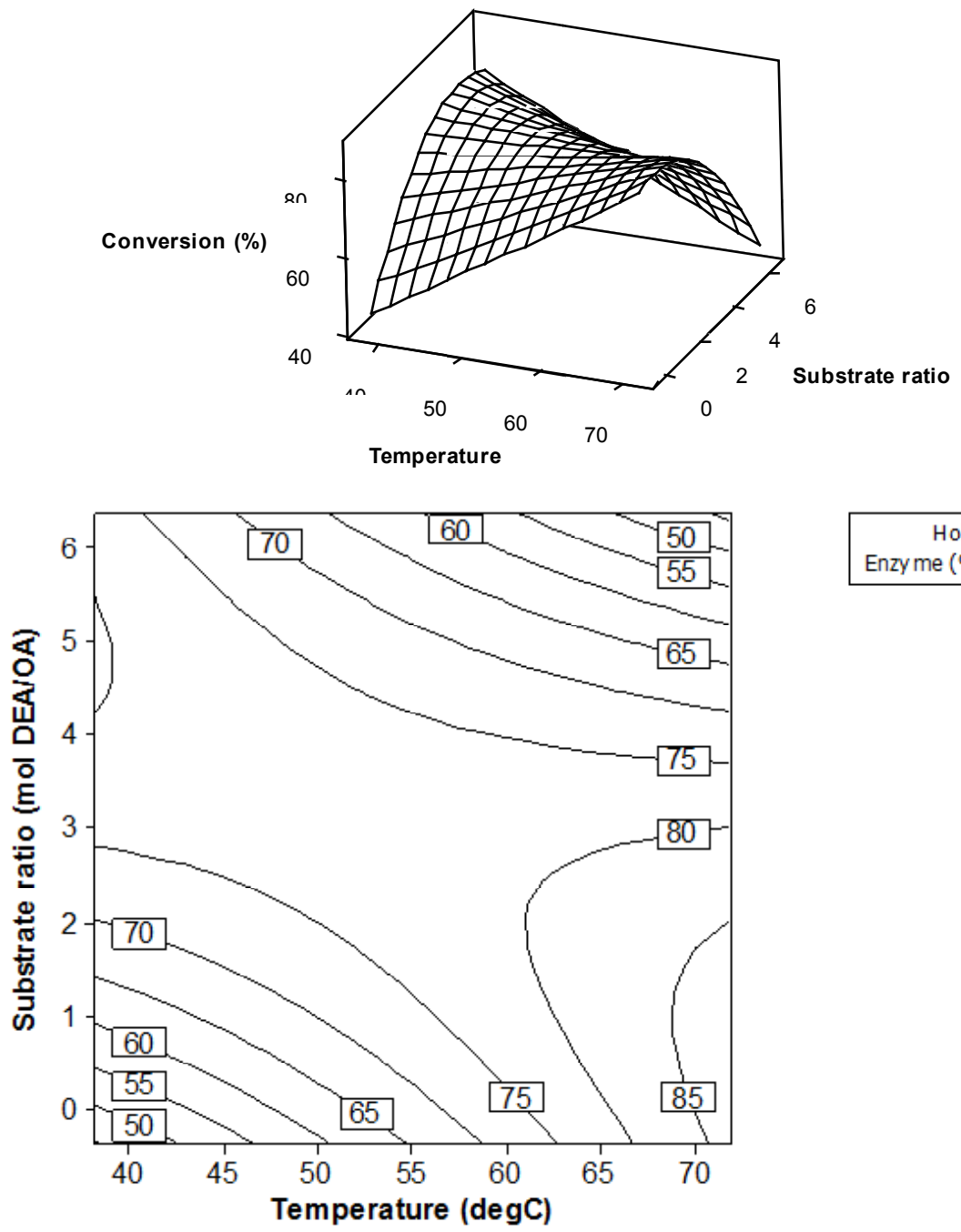

Hold Values Enzyme (\% wt/wtoA) 7

Fig. 3: Response surface plot and contour plot shows the interaction between temperature and substrate molar ratio DEA/OA with enzyme amount fixed at $7 \%$ (wt/wtOA) 
amount and temperature, were analyzed by surface response and contour response. The response is plotted by using substrate molar ratio as $X$ axis, enzyme as $Y$ axis, and the response of oleic acid conversion as $Z$ axis, while the condition of the mind variable is kept constant. From the response, it can be obtained the variable level in which the conversion of oleic acid is optimum. Contour response and surface response at the observation of the interaction effect of molar ratio DEA/OA and enzyme amount against the oleic acid conversion are shown in Fig. 2. Surface expression of the curve shows that the optimum condition of the reaction is at the center of curvature of the curve. It is possible to use a moderate amount of enzyme and molar ratio between the ranges of observed magnitudes.

Contour expression shows that oleic acid conversion increases with a substrate molar ratio to a certain limit. At high substrate concentrations, the possibility of amidification reaction the greater because of high possibility of collisions among particles. Further increase of the molar ratio decreases the conversion because when the molar ratio of substrate exceeded the optimum then the active space of the reaction is reduced so that reducing the possibility of particle collisions. This is consistent with the statistical analysis wherein
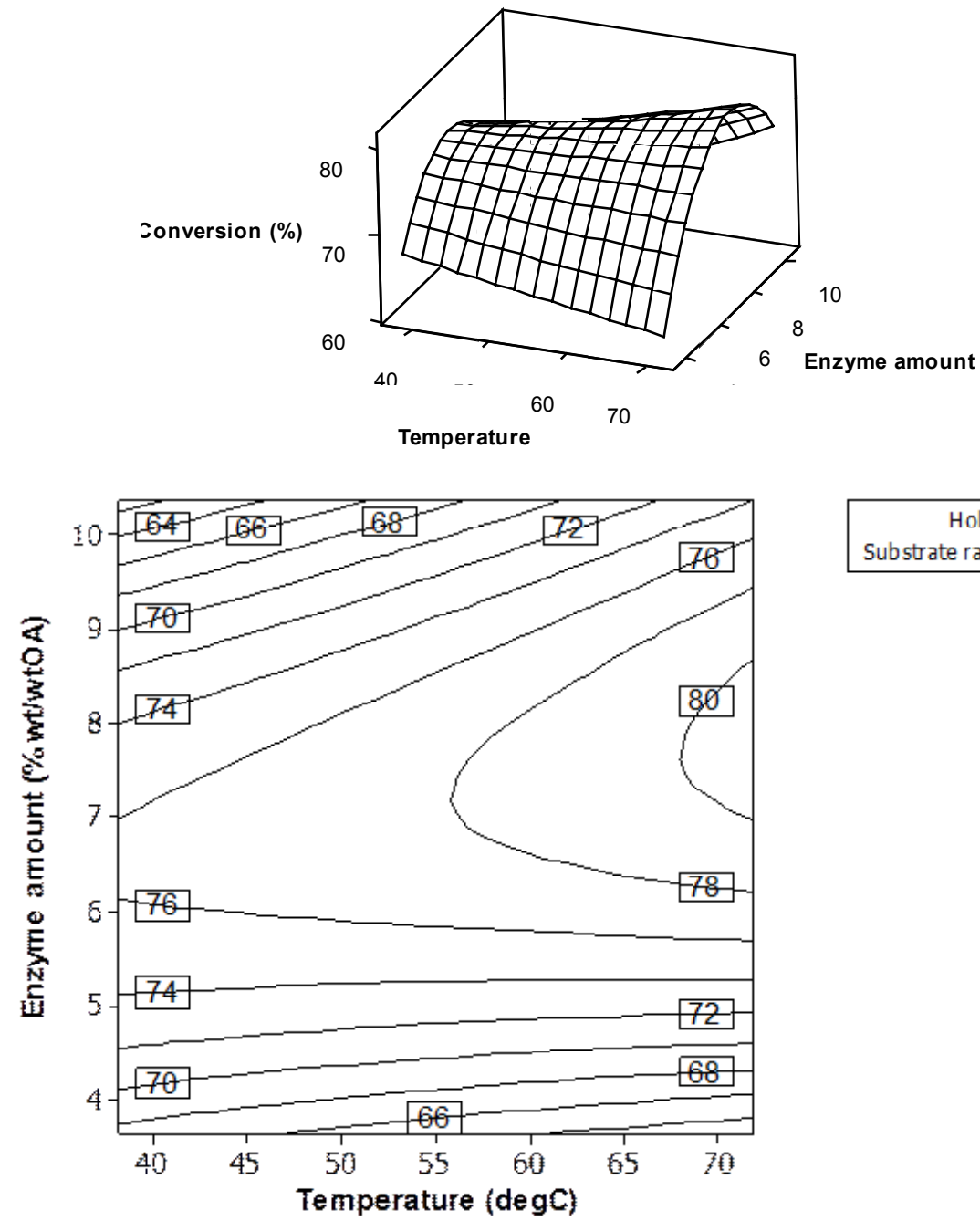

Hold Values
Substrate ratio (DEA/OA) 3

Fig. 4: Response surface plot and contour plot shows the interaction between temperature and enzyme amount with substrate molar ratio fixed at 3/1 (mol DEA/OA) 
further increase of the molar ratio gives a negative and significant effect of -3.5150 . However the influence of the interaction between molar ratio and enzyme amount gives a positive and a significant effect of 6.0914 meaning increasing the conversion of oleic acid. It is possible because increasing in enzyme amount which is followed by the increase of the substrate molar ratio allows the high enzyme substrate complex ${ }^{5}$. The surface contour also indicates that the maximum oleic acid conversion can be obtained at substrate molar ratio of 1/1?3.5/1 (mol DEA/OA) and enzyme amount at 5.5-9\% (wt/ wtOA). At this condition, the amide conversion can be reached up to $78.01 \%$.

Fig. 3 shows plot of contour response and surface response on the observation of the interaction effect of temperature and molar ratio DEA/OA on oleic acid conversion. From the contour response in Fig. 3, it can be seen that the design temperature range of $60-65^{\circ} \mathrm{C}$ produces the optimum oleic acid conversion. At this range of temperature level, more likely an increase in lipase activity in the amidification reaction. The molar ratio range that produces optimum conversion is $1 / 1-3 / 1$. Under this condition, the increasing substrate molar ratio increases the oleic acid conversion. However, further increase in the substrate molar ratio would likely result in a sharp decrease in oleic acid conversion. It is due to the barrier product where the enzyme active space binds to the substrate has full, thus the enzyme no longer able to synthesize the substrate.

So even though the temperature increased but the maximum of molar ratio is more significantly restricted the movement of enzymes. The results are in line with the results of analysis of variance where the influence of substrate molar ratio is more dominant than the effect of temperature and enzyme amount. Selectivity of the reaction is influenced by the acid-based reaction conditions where the acid-based conditions are determined by the selection of the proper substrate molar ratio. The reaction media is acidic when the ratio of amine and oleic acid is less than one. Under this condition, amine groups are protonated and then cannot be reacted with the acyl enzyme. It encourages the

$\begin{array}{rrr}\text { A } & 23.7 \% & 21817.0 \\ \text { B } & 3.4 \% & 3152.0 \\ \text { C } & 21.2 \% & 19567.2 \\ \text { D } & 16.2 \% & 14921.0 \\ \text { E } & 6.7 \% & 6172.3 \\ \text { F } & 100.0 \% & 92236.1 \\ \text { G } & 7.2 \% & 5601.9\end{array}$

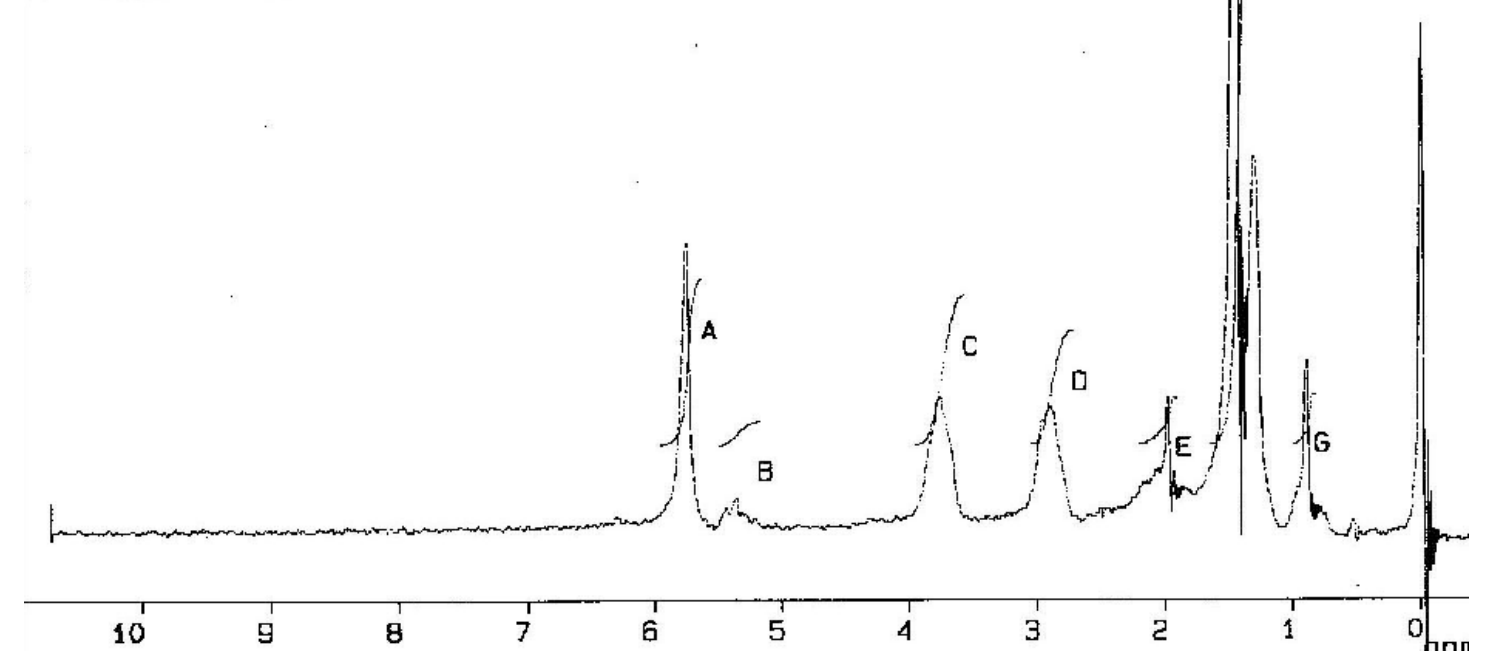

Fig. 5: Spectra results ${ }^{1} \mathrm{H}-\mathrm{NMR}$ Oleoyl-diethanolamide using TMS as the internal standard and $\mathrm{CDCl}_{3}$ as a solvent 
diethanolamine esterification. On the other hand, if the ratio amine and oleic acid is greater than one, the media reaction is alkaline and amidification reaction is more dominant because there is more reactive amine group. The ratio diethanolamine and oleic acid of 1 and 3 is noted as an optimum results and a good compromise between high conversion and enzyme chemo-selectivity. The observations are in line with Zhang and associates ${ }^{1}$, which concluded that the addition of base through increased amine ratio to the reaction mixture would increase the yield of amidification.

The interaction effect of temperature and enzyme amount on oleic acid conversion is indicated by the contour response and surface response in Fig. 4. Contour response plot shows that at enzyme amount less than 6\% (wt/wtOA), the increasing of temperature almost has no impact to the increasing of the value of oleic acid conversion. The conversion increases and reaches its optimum when the enzyme amount of $6 ? 9 \%$ (wt/wtOA). In this concentration ranges, the increasing of enzyme is greatly affecting the acquisition of the alkanolamide. The increasing amount of enzyme, at fixed temperature, initially increases product recovery but at the end addition of enzyme reduces the yield, and the optimum conversion is obtained at temperature range of $60 ? 65^{\circ} \mathrm{C}$.

This result corresponds with the results of analysis of variance where the linear effect of concentration and temperature has positive and significant impact on product formation. The quadratic effect of enzyme amount and temperature has a negative effect on product formation but the quadratic effect of the enzyme amount is very significant compared to temperature. This means that there is limitation of enzyme addition into reaction ${ }^{9}$ and further additions actually reduces the oleic acid conversion. In general, the use of a large number of enzymes increase fatty acid conversion ${ }^{21}$ because a large amount of enzymes increases the amount of acyl donor to form the acyl-enzyme complex. The analysis of variance shows that there is limitation of enzyme amount to be added into reaction.

\section{Proton Nuclear Magnetic Resonance analysis}

Proton Nuclear Magnetic Resonance ( $\left.{ }^{1} \mathrm{H}-\mathrm{NMR}\right)$ analysis of oleoyl-diethanolamide is presented in Fig. 5. On the spectrum obtained from 7 environment proton chemical shifts, that is $\delta=0.9 \mathrm{ppm}(\mathrm{t}, 3 \mathrm{H}) ; 1.4 \mathrm{ppm}(\mathrm{m}, 28 \mathrm{H}) ; 2.1 \mathrm{ppm}(\mathrm{t}$, 2H); 2.9 ppm (s, 4H); 3.7 ppm (m, 4H); 5.3 ppm (s, $1 \mathrm{H})$; and $5.7 \mathrm{ppm}(\mathrm{s}, 2 \mathrm{H})$. Chemical shift at $\mathrm{d}=0.9$ ppm $(\mathrm{t}, 3 \mathrm{H})$ shows three proton from $\mathrm{CH}_{3}$ at the end of the chain oleoyl-diethanolamide compound. $d=1.4$ $\mathrm{ppm}(\mathrm{m}, 28 \mathrm{H})$ showing 28 pieces protons on group $-\left(\mathrm{CH}_{2}\right)_{n}{ }^{-}$. While the chemical shift in $\mathrm{d}=2.1 \mathrm{ppm}(\mathrm{t}$, $2 \mathrm{H}$ ) showing 2 pieces protons on group $\mathrm{CH}_{2}-\mathrm{C}=\mathrm{O}$. For $\mathrm{d}=2.9 \mathrm{ppm}(\mathrm{s}, 4 \mathrm{H})$ showing 4 pieces protons on group $\mathrm{CH}_{2}-\mathrm{N}-\mathrm{CH}_{2}$. Chemical shift at $\mathrm{d}=3.7 \mathrm{ppm}$ $(\mathrm{m}, 4 \mathrm{H})$ showing 4 pieces protons on group $\left(\mathrm{CH}_{2}\right)$ $\mathrm{OH}$. Chemical shift at $\mathrm{d}=5.3 \mathrm{ppm}(\mathrm{s}, 1 \mathrm{H})$ is given by allylic proton $\mathrm{HC}=\mathrm{CH}$. Where as chemical shift at $\mathrm{d}=$ $5.7 \mathrm{ppm}(\mathrm{s}, 2 \mathrm{H})$ showing 2 pieces protons on group $-\mathrm{OH}$ at the end of the chain oleoyl-diethanolamide compound.

\section{CONCLUSION}

Response Surface Modeling can be used to predict the model, observe the effect of the interaction of these three variables trial and determine the optimum oleic acid conversion. Substrate molar ratio has the most significant effect on the conversion of oleic acid and interaction effects of variables, substrate molar ratio, temperature and enzyme concentration, shows that oleic acid conversion will increase with increasing values of these three variables. From the model predicted, optimum oleic acid conversion $78.01 \%$, obtained in enzyme amount $5-9 \%$ (wt/wtOA), substrate molar ratio 1/1-3/1 (mol $\mathrm{DEA} / \mathrm{OA})$ and temperature $60-65^{\circ} \mathrm{C}$.

\section{REFERENCES}

1. Zhang, J.; Cai, D.; Wang, S.; Tang, Y.; Zhang, Z.; Liu, Y.; Gao, X. Can. J. Chem. Eng. 2014, 92, 871-875.

2. Al-Mulla, E.A.J.; Wan Yunus, W.M.Z.; Ibrahim, N.A.; Rahman, M.Z.A. J. Oleo Sci. 2010,
59(2), 59-64.

3. Galilee, U.S.; Modesto, T.C.; Soma, C. Philipp. J. Sci. 2009, 138, 49-54.

4. Hoidy, W.H.; Ahmad, M.B.; Al-Mulla, E.A.J.; Wan Yunus, W.M.Z.; Ibrahim, N.A. Orient. J. 
Chem. 2010, 26(2), 369-372.

5. Masyithah, Z.; Herawan, T.; Sembiring, S.B.; Alfian, Z. Indones. J. Chem. 2011, 11, 223228.

6. Loh, P.L.; Hassan, N.H.; Yusop, M.R. Orient. J. Chem. 2014, 30(4), 1535-1543.

7. Tufvesson, P., Tornvall, U., Carvalho, J., Karlsson, A.J., Hatti-Kaul, R. J. Mol. Catal. B-Enzym. 2011, 68, 200"205.

8. Chaibakhsh, N.; Rahman, M.B.A.; Basri, M.; Salleh, A.B.; Abd-Azis, A. Biotechnol. J. 2010, 5, 848-855.

9. Graebin, N.G.; Martins, A.B.; Lorenzoni, A.S.; Garcia-Galan, C.; Fernandez-Laufente, R.; Ayub, M.A.; Rodrigues, R.C. Biotechnol. Prog. 2012, 28, 406-416. DOI 10.1002/btpr.1508.

10. Tufvesson, P.; Annerling, A.; Hatti-Kaul, R.; Adlescrent, D. Biotechnol. Bioeng. 2007, 97(3), 447-453.

11. Pan, Q.; Yang, L.; Meng, X. J. Am. Oil Chem. Soc. 2013, 90, 501-509. DOI 10.1007/ s11746-012-2186-8

12. Gaffari-Moghaddam, M.; Yekke-Ghasemi, Z.; Khajeh, M.; Rakhshanipour, M.; Yasin, Y.
Russ. J. Bioor. Chem. 2014, 40(3), 252-262.

13. Masyithah, Z. Optimasi sintesis surfaktan alkanolamida dari asam laurat dengan dietanolamina dan N-metil glukamina secara enzimatik. PhD dissertation, 2010, North Sumatera Univ, Indonesia.

14. Chau, C.M.; Liu, K.J.; Lin, C.H. Bioresour. Technol. 2011, 102, 10136-10138.,

15. Rahman, M.B.A.; Jarmi, N.I.; Chaibakhsh, N.; Basri, M. J. Microb. Biotechnol. 2011, 38, 229-234.

16. Bressani, A.P.P.; Garcia, K.C.A.; Hirata, D.B.; Mendes, A.A. Bioprocess Biosyst. Eng. 2014, 38(2), 287-297, DOI 10.1007/s00449-1041267-5.

17. Qi, J.F.; Wang, X.Y.; Zhang, H,.; Lee, J.H. Food Sci. Biotechnol. 2014, 23, 1129-1136. DOI 10.1007/s10068-014-0154-9

18. Singh, A.K.; Mukhopadhyay, M. Arab J. Sci. Eng. 2014, 39, 2463-2474. DOI 10.1007/ s13369-013-0919-0

19. Kuo, C.F.; Hsiao, F.W.; Dai, S.M.; Chang, .M.; Lee, C.C.; Liu, Y.C.; Shieh, C.J. Bioprocess Biosyst. Eng. 2012, 35, 1137-1145. 